\title{
Determining State's Financial Losses in Corruption: An Institutional Power and Constraint in Indonesia
}

\author{
I Made Gemet Dananjaya Suta* \\ Udayana University, Indonesia \\ I Gusti Agung Mas Prabandari \\ Airlangga University, Indonesia \\ Ni Luh Gede Astariyani \\ Udayana University, Indonesia
}

\begin{abstract}
One of the main elements in corruption is the loss of state finances. It results in confusion impacting law enforcement officials' performance in eradicating corruption. In Indonesia, the Supreme Audit Agency (BPK) is an institution authorized to assess state financial losses. In practice, the Financial and Development Supervisory Agency (BPKP) is another institution with similar power. This study analyzed which institutions have the more appropriate power in determining state financial losses in corruption. Using legal research with statutory and conceptual approaches, this study showed that the BPK is an institution granted the constitutional power to examine state finances' management and responsibility, asserting its more legitimate institution to handle the power to assess the financial losses. Consequently, the BPK is the only state institution that can determine state financial losses. At the same time, the BPKP is only authorized to assess or audit the calculation of state financial losses as an indication of irregularities detrimental to state finances. This study concluded that only the BPK can assess and determine state financial losses used in examining the alleged corruption before the court.
\end{abstract}

KEYWORDS: Institutional Powers, Financial Audit Institution, Corruption.

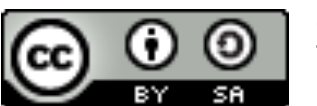

Copyright @ 2021 by Author(s)

This work is licensed under a Creative Commons Attribution-ShareAlike 4.0 International License. All writings published in this journal are personal views of the authors and do not represent the views of this journal and the author's affiliated institutions.

HOW TO CITE:

Suta, I Made Gemet Dananjaya, et al., "Determining State's Financial Losses in Corruption: An Institutional Power and Constraint in Indonesia" (2021) 8:1 Lentera Hukum 95-114. DOI: <https://doi.org/ 10.19184/ejlh.v8i1.21923>.

Submitted: 09/01/2021 Reviewed: 12/01/2021 Revised: 20/03/2021 Accepted: 04/04/2021

* Corresponding author's e-mail: danan.ade@gmail.com 


\section{INTRODUCTION}

As part of serious crimes, corruption becomes one of the critical challenges that hinder development in many developing countries. Countries such as Indonesia and the Philippines have struggled to eradicate corruption, resulting in complex governance. ${ }^{1}$ Corruption is still classified as very high in Indonesia, and it gradually increases from the central to regional levels. It harms economic growth and the development of national infrastructure.

Currently, the scale of corruption in Indonesia is much broader and more systematic. The increasing practice of corruption has become a severe problem for law enforcement efforts in Indonesia. ${ }^{2}$ According to Indonesia Corruption Watch (ICW), there were 271 cases of corruption in 2019, and in the first half of 2020, this figure was decreased by 169 cases. $^{3}$ Although the number of corruption cases was decreased, state losses in 2020 were increased to a value of IDR 18.1 trillion, ${ }^{4}$ which was only IDR 8.04 trillion in the previous year. ${ }^{5}$ The increasing number of corruptions in Indonesia, both in terms of quantity of state financial losses and the quality of the corruption carried out systematically. Therefore, corruption becomes the fundamental issue in response to the loss of state finance.

Before determining the state financial loss, it is necessary to have a clear juridical definition. Article 1(1) of State Finance Law 17/2003 defines state finance as all the rights and obligations of the state valued in money and everything in the form of money or goods used as state property. ${ }^{6}$ According

1 Jon ST Quah, "Combating police corruption in five Asian countries: a comparative analysis" (2019) 9:2 Asian Educ Dev Stud 197-216 at 198.

2 M Agus Santoso, "Dampak Penjatuhan Pidana Korupsi Bagi Pegawai Negeri Yang Sedang Menjalankan Tugas Administrasi Negara” (1969) 7:2 J Borneo Adm 129-153.

3 Sania Mashabi, "ICW: Ada 169 Kasus Korupsi Sepanjang Semester I 2020”, (2020), online: <https://nasional.kompas.com/read/2020/09/29/16112851/icw-ada-169kasus-korupsi-sepanjang-semester-i-2020>.

4 Ibid.

5 Ardito Ramadhan, "Catatan ICW, Tren Penindakan Korupsi Turun Jadi 271 Kasus”, (2020), online: <https://nasional.kompas.com/read/2020/02/18/16532131/ catatanicw-tren-penindakan-korupsi-turun-jadi-271-kasus $>$.

6 Karel Antonius Paeh, "Pengembalian Kerugian Keuangan Negara Berdasarkan Rekomendasi Badan Pemeriksa Keuangan (BPK) Hubungan Dengan Unsur Kerugian Negara dalam Tindak Pidana Korupsi” (2017) 5:2 J Kat 49-56. 
to Article 1(22) of State Treasury Law 01/2004, state and regional losses are real and definite (nyata dan pasti) amount of deficit of money, securities, and goods due to acts against the law either deliberately or negligently. Therefore, the real and definite state financial losses must be calculated and determined to be legally accounted. Lawyers interpret the term 'real and definite' as something happened. ${ }^{7}$ This term's meanings align with the elucidation of Article 32(1) of the Corruption Eradication Law. The real and definite loss of state finances is a loss that has been calculated based on the findings of the authorized institutions. The Supreme Audit Institution or Badan Pemeriksa Keuangan (BPK) conducts audits and assessments of state financial losses. The Financial and Development Supervisory Institution or Badan Pengawas Keuangan dan Pembangunan (BPKP) can also assess state losses by referring to Government Regulation 60/2008 on government internal control systems. It was further added by Presidential Regulation $192 / 2014$ on BPKP, making it one of the government's internal supervisory apparatus, which can independently calculate state financial losses for the government's interests. This same power to examine and assess state financial losses results in a dualism between these institutions.

This dualism in determining state financial losses results in overlapping powers that impact these institutions' credibility. For instance, the financial audit to the National Electricity Company or PT PLN (Persero) for the suspect Eddie Widiono Suwondho in 2010 resulted in a different assessment and determination against the state loss results. Based on this case, the BPKP stated a loss of IDR 46,189,037,336 (USD 3,184,341) in 2006 at the PT PLN (Persero) financial audit. ${ }^{8}$ Meanwhile, the BPK has stated that the corporation did not suffer losses. ${ }^{9}$ The calculation of state financial losses has become a severe concern to eradicate corruption. The certainty is not guaranteed in implementing law enforcement against corruption, which is possible for each agency that calculates state losses to have different methods.

7 Theodorus M Tuanakotta, Menghitung Kerugian Keuangan Negara dalam Tindak Pidana Korupsi (Jakarta: Salemba Empat, 2009).

8 Constitutional Court Decision Number 31/PUU-X/2012 on the Judicial Review of Law No. 30 of 2002 on the Corruption Eradication Commission.

9 Constitutional Court Decision Number 31/PUU-X/2012 on the Judicial Review of Law No. 30 of 2002 on the Corruption Eradication Commission. 
The dualism of institutions that provide audit results for state losses confuses the meaning of the real and definite state financial losses. Therefore, it is necessary to discuss further which institution is more authorized to determine the occurrence of a real and definite amount of state financial losses, which is then used as the basis for examination before the court on suspicion of corruption.

This study aimed to analyze which institutions have the power to determine state financial losses in corruption. Two parts in the discussion identify powers granted to the BPK and the BPKP following their conflicts in assessing and determining state financial losses in corruption. The first part discusses the powers of the BPK and the BPKP in assessing and determining state financial losses. The first part is divided into two sections. The first section discusses the role and position of the BPK and the BPKP in the Indonesian constitutional structure. In this subpart, the concept of separation of power, checks and balances, and trias politica connected with the Indonesian context. The second discusses the powers of the BPK and the $\mathrm{BPKP}$ in assessing and determining state financial losses in corruption. In this subpart, the discussion is carried out by applying the concept of acquiring power or authority through attribution, delegation, and mandate. The second part of the discussion deals with the relationship between the BPK and the BPKP in overlapping power over state financial losses in corruption.

\section{METHODS}

This research method was a juridical research method by examining the legal norms in statutory regulations. It examined legal norms as objects by looking at law from an internal perspective, ${ }^{10} \mathrm{~A}$ conceptual approach referred to doctrines in legal scholarship. using statutory and conceptual approaches. A statutory approach used legislation and related laws to legal issues, namely by considering the norm structure in a hierarchy of statutory regulations. It collected primary legal materials, consisted of statutory regulations and

10 I Made Pasek Diantha, Metode Penelitian Hukum Normatif Dalam Justifikasi Teori Hukum (Jakarta: Prenadamedia Grup, 2019). 
secondary legal materials, such as books, journals, and other related academic sources.

\section{INSTITUTIONAL DISCOURSES IN ASSESSING STATE FINANCIAL LOSSES}

\section{A. The BPK and the BPKP in the Indonesian Constitutional Structure}

The discussion on the role of a state institution links to an understanding of the constitutional structure. Indonesia's constitutional structure refers to the 1945 Constitution. The functions and powers of each institution are strongly influenced by the principle or thought that Montesquieu introduced as the separation of powers or trias politica. ${ }^{11}$ This doctrine suggested separating powers in the three branches of state power. ${ }^{12}$ They are the legislative branch that constitutes a statutory regulation, ${ }^{13}$ executive branch that carries out statutory regulation, ${ }^{14}$ judicial power that upholds justice or the prevailing statutory regulations. ${ }^{15}$ Kelsen criticized this concept with two primary functions of the state. They are creating and applying the law, where these functions are not coordinated but can be distributed to several institutions. ${ }^{16}$ Kelsen argued the impossibility of establishing a boundary that separates these functions from one another because their differences between the creation and application of the law have only a relative character. ${ }^{17}$ Instead, most state actions are at the same time actions that create and enforce laws. ${ }^{18}$

11 Haposan Siallagan, "Problematics on Separation of Powers Theory Implementation" (2015) 15:3 J Din Huk 324-330.

12 Efi Yulistyowati, Endah Pujiastuti \& Tri Mulyani, "Penerapan Konsep Trias Politica Dalam Sistem Pemerintahan Republik Indonesia : Studi Komparatif Atas UndangUndang Dasar Tahun 1945 Sebelum Dan Sesudah Amandemen” (2017) 18:2 J Din Sos Budaya 328-338.

13 Syofyan Hadi, "Fungsi Legislasi Dalam Sistem Pemerintahan Presidensil (Studi Perbandingan Indonesia dan Amerika Serikat)” (2013) 9:18 DIH J Ilmu Huk 78-84.

14 Ibid.

15 Ibid.

${ }^{16}$ Hans Kelsen, Hans Kelsen, General Theory of Law and State, translated by Anders Wedberg (New York: Russell \& Russell 1961).

17 Ibid.

18 Ibid. 
Indonesia does not purely adhere to the trias politica of Montesquieu. Ismail Sunny stated that Indonesia does not adhere to a separation of powers in a material sense but a division of power. ${ }^{19}$ The three branches of power are carried out based on power-sharing by state institutions. ${ }^{20}$ First, the legislative power is handed by the House of Representatives, the Regional House of Representatives, and the President, where the President can submit a draft law and jointly with DPR approve the draft to become a law. Second, the President exercised the executive power, assisted by Vice President, Ministers, and other state institutions under the President. Third, the judicial power is exercised by the Supreme Court and the Constitutional Court.

Although the three powers are separated based on their respective tasks, in carrying out state administration, they are carried out based on a dynamic working relationship mechanism between state institutions, known as the principle of checks and balances ${ }^{21}$ in the framework of carrying out state duties. $^{22}$ The legislative, executive, and judicial branches of powers are all equal and control each other under checks and balances. ${ }^{23}$ With checks and balances, state power can be regulated, limited, and even appropriately controlled. ${ }^{24}$ Thus, abuse of power by state administrators or individuals who happen to be occupying positions in the relevant state institutions can be prevented and handled correctly. ${ }^{25}$

19 Muchamad Ali Safa'at, "Sengketa Kewenangan Lembaga Negara."

${ }_{20}$ Muhammad Imron Rosyadi, "Wewenang Badan Pemeriksa Keuangan dan Badan Pengawasan Keuangan dan Pembangunan Dalam Menilai Kerugian Keuangan Negara” (2016) Mimb Keadilan 26-53.

21 Faharudin, "Prinsip Checks and Balances Ditinjau Dari Sisi dan Praktik" (2017) 1:2 J Huk Volkgeist 115-128.

22 Syofyan Hadi, "Prinsip Checks And Balances Dalam Struktur Lembaga Perwakilan Rakyat Di Indonesia (Studi Terhadap Usulan Perubahan Kelima UUD NRI Tahun 1945)" (2014) Edisi: Jan Mimb Keadilan 49-59.

23 Sunarto, "Prinsip Checks and Balances Dalam Sistem Ketatanegaraan Indonesia" (2016) 45:2 Masal-Masal Huk 157-163.

${ }^{24}$ Faharudin, supra note 21.

25 Jimly Asshiddiqie, Konstitusi dan Konstitusionalisme (Jakarta: Sekretariat Jenderal dan Kepaniteraan Mahkamah Konstitusi Republik Indonesia, 2006). 
Apart from the three branches of power mentioned above, in Indonesia itself, based on Article 23E of the 1945 Constitution, other branches of power function to examine state finances' management and responsibility. This institution is the BPK. The BPK was formed based on the mandate of Article $23 \mathrm{E}$ of the 1945 Constitution, which regulates to examine the management and responsibility of state finances, a free and independent Supreme Audit Agency (BPK) shall be established, whose duties and powers are further regulated in BPK Law. Article 1:1 of BPK Law stipulates that the BPK is a state institution tasked with examining the management and accountability of state finances as referred to in the 1945 Constitution. It can be due to the need for an independent institution, ${ }^{26}$ exempted from the doctrine of the trias politica institutions. Thus, the BPK plays an essential role in adding checks and balances among the powers of state institutions, especially the management audit of state finances ${ }^{27}$ carried out by the executive, where the financial audit is an integral part of the supervision function toward government performance in general. ${ }^{28}$ The Decree Number VI/MPR/2002 by the People's Consultative Assembly or Majelis Permusyawaratan Rakyat (MPR) also strengthens the position of the BPK as the only external audit institution for state finance. ${ }^{29}$ While the 1945 Constitution stated the BPK was established to examine the management and responsibility of the state finance, ${ }^{30}$ such a function is vital in examining

26 Rizki Ramadani, "Lembaga Negara Independen Di Indonesia Dalam Perspektif Konsep Independent Regulatory Agencies” (2020) 27:1 J Huk Ius Quia Iustum 169192.

${ }^{27}$ Mieke Rayu Raba, "Peran Badan Pemeriksa Keuangan (BPK) Dalam Melakukan Pemeriksaan Terhadap Pengelolaan Keuangan Negara Untuk Mewujudkan Pemerintahan yang Baik Menurut UU No. 15 Tahun 2006” (2017) 6:3 Lex Crim 152160.

28 Jimly Asshiddiqie, Perkembangan dan Konsolidasi Lembaga Negara Pasca Reformasi (Jakarta: Sekretariat dan Kepaniteraan Mahkamah Konstitusi Republik Indonesia, 2006).

29 Raba, supra note 27.

30 Beni Kurnia Illahi \& Muhammad Ikhsan Alia, "Pertanggungjawaban Pengelolaan Keuangan Negara Melalui Kerja Sama BPK dan KPK” (2017) 3:2 Integritas J Antikorupsi 37-78. 
the management and responsibility of state finance. ${ }^{31}$ In carrying out its tasks, it is expected that any power will not interfere with the BPK for having the objective audits that improve good governance.

On the other hand, the BPKP has emerged as an institution with similar tasks to the BPK. The BPKP was established as an internal supervisor on state financial accountability. ${ }^{32}$ In other words, it is an internal supervisory apparatus responsible to the President. Therefore, the BPKP is not an autonomous institution but within the scope of executive power, which has the task to supervise the management of state finances conducted by the government. ${ }^{33}$

Jimly Asshiddiqie argues that limiting a centralized power in one organ allows arbitrariness, despite a growing idea of creating independent state institutional organizations in modern countries. ${ }^{34}$ As also happened in Indonesia, the state institutional organization changes consist of two components. They are the growing awareness that certain state bodies such as bodies or commissions that hold general elections, state central banks, and state financial management auditing bodies must be developed independently. ${ }^{35}$ The independence of these institutions is necessary to ensure a more effective limitation of power and democratization. ${ }^{36}$ The independence of such an institution is significant because the investigating officer may not be interfered with the interests of the party being examined or other parties who have direct or indirect interests, thereby affecting the objectivity of the examination. ${ }^{37}$

31 Fery Aferio, "Kebebasan dan Kemandirian Badan Pemeriksa Keuangan Dalam Pengawasan Penggunaan Keuangan Negara Berdasarkan Undang-Undang Dasar Negara Republik Indonesia Tahun 1945” (2015) 2:2 J Online Mhs FH UNRI 1-15.

32 Adam Setiawan, "Eksistensi Lembaga Pengawasan Pengelolaan Keuangan Negara" (2019) 49:2 J Huk Pembang 265-278.

33 Ni'matul Huda, "Potensi Sengketa Kewenangan Lembaga Negara dan Penyelesaiannya di Mahkamah Konstitusi” (2017) 24:2 J Huk IUS QUIA IUSTUM 193-212.

34 Asshiddiqie, supra note 25.

35 Rosyadi, supra note 20.

${ }^{36}$ Jimly Asshiddiqie, Konstitusi dan Kontitutionalisme Indonesia (Jakarta: Sinar Grafika, 2011).

37 Rosyadi, supra note 20. 
Accordingly, the power granted to the BPK is more comprehensive than that to the BPKP. Despite the constitutional basis dedicated to the BPK in auditing the state finance, the scope covers all elements of the state finance with a mandatory working. ${ }^{38}$ According to their respective powers, the results of the audit are subsequently submitted to the House of Representatives, the Regional Representative Council, and the Regional Houses of Representatives, one of which is to supervise the administration by the executive institution. ${ }^{39}$ Meanwhile, the BPKP is tasked with conducting internal supervision of state financial accountability for certain activities, including cross-sectoral activities, activities of the state general treasury, and other activities based on an assignment from the President. ${ }^{40}$ The reports of the BPKP supervision are periodically submitted to the President. ${ }^{41}$

B. Betweeen the BPK and the BPKP: Powers in Assessing State Financial Losses Before discussing the powers of the BPK and the BPKP, it is crucial to understand the concept of authority or power and howhow to obtain it. As Indonesia adopted the civil law tradition, it is commonly agreed that Indonesia almost refers to the Dutch-based law. Authority in Dutch is called bevoegheid or competentie, which means authority or power. ${ }^{42}$ In the Indonesian language, the word authority means kerwenangan or the right and power to act. It is also defined as the power to make decisions, rule, and delegate responsibilities to others. While Robert Bierstedt defined authority as institutionalized power, ${ }^{43}$ Bagir Manan considered authority as different

38 R Bayu Ferdian, Mohd Din \& M Gaussyah, "Penetapan Kerugian Negara Dalam Perkara Tindak Pidana Korupsi” (2018) 2:3 Syiah Kuala Law J 320-337.

39 Article 23E(2) of the 1945 Constitution in conjunction with Article 17 of BPK Law.

40 Article 49(2) of PP 60/2008.

41 Article 54 of PP 60/2008.

${ }^{42}$ NE Algra \& HRW Gokke, Fockema Andreae's Rechtsgeleard Handwoordenboek, translated by Saleh Adiwinata et al, Kamus Istilah Hukum Fockema Andreae BelandaIndonesia (Jakarta: Binacipta, 1983).

43 Firmansyah Arifin et all, Lembaga Negara dan Sengketa Kewenangan Antarlembaga Negara (Jakarta: Konsorsium Reformasi Hukum Nasional (KRHN), 2005). 
as power. The power only describes the right to act and not to act, ${ }^{44}$ but the authority is the right to use the authority of an official or institution according to applicable provisions. ${ }^{45}$ Tatiek Sri Djatmiati defined authority as legitimacy given by the constitution to public bodies to carry out their functions. ${ }^{46}$

Philipus M. Hadjon stated the authority is about making decisions obtained in two ways: attribution and delegation. The notions of attribution and delegation are tools that help check whether a body or institution bears the authority. ${ }^{47}$ The powers of state institutions can be obtained through attribution, delegation, or mandate. ${ }^{48}$ There is the formation of authority or power in attribution because it comes from a situation with no authority. The establishment of this authority leads to new powers that are original. The source of this original authority is primarily the constitution. This is because the establishment of authority coincides with the establishment of the institution which obtains the authority. Under what was stated by Henk Van Maarseveen, the constitution is a "reglement van attributie" or attribution regulation. ${ }^{49}$ Government Administration Law 302014 stated that attribution is granting authority to institutions by the laws. Moreover, Article 1(23) explains that delegation is a transfer of authority from a higher to a lower body with the responsibility and accountability transferring entirely to the recipient of the delegation. In Article 1(24), the mandate transfers authority from a higher to a lower institution with the responsibility and liability remains with the mandator.

The BPK is a state organ or institution whose authority derives from Articles 23E-23G of the 1945 Constitution, examining state finances' management and responsibility, further regulated in BPK Law. Therefore, the authority

${ }^{44}$ Ridwan HR, Hukum Administrasi Negara (Jakarta: PT Raja Grafindo Persada, 2013).

45 Ibid.

46 Tatiek Sri Djatmiati, Prinsip Izin Usaha Industri di Indonesia (Surabaya: Universitas Airlangga, 2003).

47 Philipus M Hadjon, Pengantar Hukum Administrasi Indonesia (Yogyakarta: Gajah Mada University Press, 2011).

48 Ibid.

49 Suwoto Mulyosudarmo, Peralihan Kekuasaan: Kajian Teoritis dan Yuridis terhadap Pidato Nawaksara (Jakarta: Gramedia Pustaka Utama, 1997). 
of the BPK in conducting audits of the management and responsibility of state finances is the authority of attribution ${ }^{50}$ because it comes from the Constitution and/or Laws. ${ }^{51}$ It is clear that the BPK has a position not above or below the executive (government), legislative or judicial branches of power but is outside the three branches of power, which are equal and independent.

On the other hand, BPKP's power derives from Article 49 of PP 60/2008, namely as an internal supervisor of state financial accountability whose tasks are further regulated in the Presidential regulation. The BPKP power in carrying out internal supervision of state finances is under the delegation, ${ }^{52}$ namely as the delegted authority (through the BPKP Presidential Decree) by the President ${ }^{53}$ as the holder of state government power (executive). Therefore, the BPKP cannot have oversight of state finances that exceeds the executive power. The BPKP as an internal supervisory institutional (internal auditor), supervises within the same branch of power, that is, both within the scope of executive power. ${ }^{54}$ The BPKP is limited to supervising state finances related to the implementation of government power. The aim is to provide sufficient confidence that the government activities have been carried out effectively and efficiently under established benchmarks for good governance. ${ }^{55}$

The BPK, an independent external auditor, examines state finances' entire management and responsibility in every activity of state administration. As stated in the preamble considering letter "a" of BPK Law, state finance is one of the main elements in the administration. It has significant benefits in realizing the state's goal of achieving a just, affluent and prosperous society. Therefore, the BPK plays a critical role in auditing the management and accountability of state finances, which has a relationship with the legislative power in supervising government actions.

\footnotetext{
50 Rosyadi, supra note 20.

51 Setiawan, supra note 32.

52 Rosyadi, supra note 20.

53 Setiawan, supra note 32.

${ }^{54}$ Rosyadi, supra note 20.

55 Article 1(3) of PP 60/2008.
} 
The BPK examines the management and responsibility of state finances carried out by the central and regional governments and other state institutions. It includes the central bank, state-owned enterprises, regionalowned enterprises, and public service bodies. At the same time, while a criminal element is found in the examination, it will report to the competent authority no later than one month after the criminal element is known. ${ }^{56}$ The report as a result of the BPK examination is used as a basis by investigators to carry out investigations into alleged crimes related to the management and responsibility of state finances, which generally indicate a loss of state finances as an element of corruption. ${ }^{57}$

Based on BPK Regulation 01/2007 on the State Financial Audit Standards in Attachment VI, the inspection result functions to: (a) communicating it to the competent authorities based on the prevailing statutory regulations; (b) constituting the results of the examination avoid misunderstandings; (c) constituting the inspection result as material for taking corrective actions by the relevant institutions; and (d) following-up monitoring to determine the effect of corrective actions that should have been taken. The need to exercise responsibility for the program requires that inspection reports be presented in an easily accessible form. Therefore, the inspection result has a vital function in handling corruption cases. Through the inspection result, the government agency has been identified or has misappropriated funds, which resulted in losses to state finances. ${ }^{58}$

With regard to the assessment of state financial losses in corruption, the BPK's power as the audit institution-supervisor/examiner-for the management and responsibility of state finances to assess state financial losses in the event of suspected corruption crimes other than those stipulated in Article 10(1) and (2) in conjunction with Article 8(3) and (4) of BPK Law. This power reflects in Article 6(3) of BPK Law, which regulates that audits

${ }^{56}$ Margareth Carla Rampengan, "Fungsi Laporan Hasil Pemeriksaan (Lhp) Badan Pemeriksa Keuangan Dalam Kasus Tindak Pidana Korupsi” (2013) 2:2 Lex Crim 172-181.

57 Article 1(14) of BPK Law.

${ }^{58}$ Mahdalena Deisi Rampengan, "Fungsi Badan Pemeriksa Keuangan Dalam Pemberantasan Tindak Pidana Korupsi” (2014) 2:3 Lex Soc 44-51. 
with a specific purpose..$^{59}$ By referring to Article 6(2) of BPK Law, the interpretation to the examination with a specific purpose refers to Article 4 of the Examination of State Finance Management and Responsibility Law or UU Pemeriksaan Pengelolaan dan Tanggung Jawab Keuangan Negara (PPTJKN Law). It explains that the audit with particular objectives includes examining other matters in finance, investigative examination, and examination of the government's internal control system. Article 13 of the PPTJKN Law stipulates that the BPK as an examiner can carry out investigative examinations to reveal indications of the national and regional governments' loss and/or criminal elements. State losses are interpreted as a deficit of money, securities, and goods with a definite amount due to acts against the law, whether intentionally or negligently. Then, when an examination finds a criminal element, the BPK must immediately report the matter to the competent authority under the statutory regulations' provisions. In summary, the BPK is an institution to assess state financial losses in corruption. Article 10(1) and (2) of BPK Law outlines that the BPK can assess losses and determine the real and definite amount of state losses in the case of state financial losses.

Nevertheless, the BPKP, as another similar institution to the BPK, has the primary task of carrying out government affairs in state or regional financial supervision and national development. In practice, the BPKP carries out monitoring or auditing the calculation of state financial losses. Article 3 of the BPKP Presidential Decree states that BPKP can retard the continuity of development audits of price adjustments, audits of claims, audits of investigations of cases of irregularities that indicate losses to central or regional governments' finances, providing expert statements, and efforts to prevent corruption. The BPKP can investigate cases of irregularities indicated to cause losses to central and regional governments' finances. Therefore, the BPKP has the task to assess state financial losses but does not have the task to determine and declare the existence of state losses.

While the BPK and the BPKP are supposed to have similar power in assessing financial losses, their difference lies in the power to assess and

59 Rampengan, supra note 56. 
determine. The BPKP can assess the value of state financial losses arising from a case of irregularities. ${ }^{60}$ In the meantime, the BPK has the sole power to determine state financial losses as the basis for examining allegations of corruption within the scope of judicial power in the court. Also, the BPK can determine state financial losses caused by illegal or negligent acts committed by all organs or institutions that manage state finances. ${ }^{61}$

\section{OVERLAPPING POWERS IN DETERMINING STATE FINANCIAL LOSSES}

As previously described, the $\mathrm{BPK}$ and the $\mathrm{BPKP}$ have the power to conduct audits or assess state financial losses based on statutory regulations. The resemblance of power implies dualism of power between the BPK and the BPKP in conducting an assessment or audit of state financial losses in corruption, which creates uncertainty regarding which reports from institutions areas the basis suspected state financial losses. The power overlapping obetween the BPK and the BPKP can be examined in each institutional power. The BPK has the sole power in determining state financial losses as the basis for examining suspected corruption crimes within the scope of judicial power in court.

The assessment and determination of state financial losses in the Corruption Eradication Act are related to the trial process by a panel of judges at the Corruption Court, the judicial power scope. In examining a case in court, it takes priority despite putting forward objectivity—a trial that is independent and impartial and free from all the influence of other powers- to result in a fair decision. ${ }^{62}$ In 2016, based on the Decision of the Surabaya District Court No. 120/Pid.Sus/TPK/2016/PN.Sby, there was a case of BPKP's fake audit results regarding the corruption case in Badan Pengawas Pemiliban Umum or the East Java Election Supervisory Agency (Bawaslu). The judges decided that the three defendants were acquitted and were not proven to be corrupt

60 Regulation of the Head of BPKP No. PER-1314/K/D6/2012 on the Guidelines for the Assignment of the Field of Investigation.

${ }^{61}$ Article 10(1) of BPK Law.

${ }^{62}$ Firman Floranta Adonara, "Prinsip Kebebasan Hakim dalam Memutus Perkara Sebagai Amanat Konstitusi” (2016) 12:2 J Konstitusi 217-236. 
because the case's evidence was incomplete, and the East Java BPKP auditors were not honest.

This case reflects that it is also possible for the BPKP to produce nonobjective audits. As an internal supervisory agency, the government also does not escape the intervention from other parties. Likewise, the BPK also does not rule out the possibility that the individuals in the BPK also do not carry out their duties with integrity. The calculation results of the state's financial losses can be doubted. Therefore, the independence of an institution is essential because the investigating officer may not be interfered with by the interests of the party being examined or other parties who have direct or indirect interests, thus affecting the objectivity of the examination.

Given these possibilities, it is indispensable for the BPK as the only audit institution to determine the real and definite state financial losses. While there is an error in the audit results of state financial losses used as the basis for examination in corruption, the BPK can investigate the accountability.

The Supreme Court Decision No. 2391/K/PID.SUS/2016 stipulates the principle of other institutions other than the BPK. For instance, the BPKP, for and on behalf of the BPK, can conduct investigative audits to determine the amount of state financial losses, and the results can be accepted. The Supreme Court's consideration emphasizes that the term "for and on behalf of the BPK" shows a need for coordination between the BPK and the BPKP in determining state financial losses. Since the BPK is the institution that can declare a state financial loss. Therefore, after the BPKP issued a report on the results of an audit of state financial losses, it should forward the report to the BPK whether the calculation results can indicate a loss in state finance in examining the alleged corruption.

In Constitutional Court's Decision No. 31/PUU-X/2012, the Court explains that the Corruption Eradication Commission or KPK should not merely coordinate with the BPKP and the BPK to prove corruption cases. Instead, the commission can also coordinate with other agencies. It includes inviting experts or requesting materials from the inspectorate general or agencies that have the same function as respective government agencies, even from other parties-including companies. The emphasis on "calculating 
state financial losses" in the court's deliberations shows that the BPK and the BPKP have the same power to calculate state financial losses and other parties in calculating state financial losses. However, the power to determine and declare a state financial loss is only with the BPK, as outlined in Articles 10(1) and (2) of BPK Law. It is in line with Dian Puji Simatupang's statement as an expert in the trial for judicial review in the Constitutional Court Decision No. 31/PUU-X/2012 on the review of KPK Law 30/2002. He explained that BPKP is no longer authorized to calculate state losses. According to him, the BPK can calculate and audit state losses. BPKP could audit as long as there is permission from the President and ministers. Subsequently, while there are audit results issued simultaneously by the BPK and other institutions, law enforcers must refer to the results of the BPK because these institutions have the power to calculate and audit state losses. ${ }^{63}$ The dualism of power between the BPK and the BPKP on state financial losses in corruption was disputed. Then, it was examined at the Corruption Court trial to decide which institutions' report results to become the basis for examinations in deciding corruption that causes loss of state finances. Then, the Supreme Court, as the highest court, issued Surat Edaran Mabkamah Agung or Circular Letter 04/2016 on the enforcement of the formulation of the plenary meeting results of the Supreme Court Chamber of 2016 as guidelines for implementing tasks for courts in the legal formulation of the criminal chamber. This circular letter states that the institution authorized to declare the loss of state finances is the BPK due to its constitutional basis. In contrast, other agencies such as the BPKP/Inspectorate/Regional Work Units are authorized to carry out management audits and examine state finances. However, they are not authorized to declare a state financial loss.

${ }^{63}$ Erry Gusman, "Kedudukan BPKP dalam Mengaudit Kerugian Keuangan Negara Pasca Putusan Mahkamah Konstitusi Nomor: 31/PUU-X/2012” (2019) 1:3 Ensiklopedia Soc Rev 348-357. 


\section{CONCLUSION}

The BPK and the BPKP have the power to calculate state financial losses. However, the BPK, as a free and independent institution in supervising all other institutions or agencies that manage state finances, can assess and determine state financial losses. The BPK has constitutional power as the highest audit or supervisory agency in auditing state finances' management and responsibility. Meanwhile, the BPKP, as an institution responsible to the President, is the delegated authority from the Presidential regulation. With regard to the assessment and determination of state financial losses used in examining alleged corruption in court, the BPK is the only institution that has the power, as referred to in the Supreme Court's Circular Letter 04/2016.

\section{ACKNOWLEDGMENTS}

None.

\section{COMPETING INTEREST}

The authors declared that they have no competing interests.

\section{REFERENCES}

Adonara, Firman Floranta, "Prinsip Kebebasan Hakim dalam Memutus Perkara Sebagai Amanat Konstitusi” (2016) 12:2 J Konstitusi 217-236.

Aferio, Fery, "Kebebasan dan Kemandirian Badan Pemeriksa Keuangan Dalam Pengawasan Penggunaan Keuangan Negara Berdasarkan Undang-Undang Dasar Negara Republik Indonesia Tahun 1945" (2015) 2:2 J Online Mhs FH UNRI 1-15.

Algra, NE \& HRW Gokke, Fockema Andreae's Rechtsgeleard Handwoordenboek, translated by Saleh Adiwinata et al, Kamus Istilah Hukum Fockema Andreae Belanda - Indonesia (Jakarta: Binacipta, 1983). 
Asshiddiqie, Jimly, Konstitusi dan Konstitusionalisme (Jakarta: Sekretariat Jenderal dan Kepaniteraan Mahkamah Konstitusi Republik Indonesia, 2006).

_- Konstitusi dan Kontitutionalisme Indonesia (Jakarta: Sinar Grafika, 2011).

—_ Perkembangan dan Konsolidasi Lembaga Negara Pasca Reformasi (Jakarta: Sekretariat dan Kepaniteraan Mahkamah Konstitusi Republik Indonesia, 2006).

Diantha, I Made Pasek, Metode Penelitian Hukum Normatif Dalam Justifikasi Teori Hukum (Jakarta: Prenadamedia Grup, 2019).

Djatmiati, Tatiek Sri, Prinsip Izin Usaha Industri di Indonesia (Surabaya: Universitas Airlangga, 2003).

Faharudin, "Prinsip Checks and Balances Ditinjau Dari Sisi dan Praktik" (2017) 1:2 J Huk Volkgeist 115-128.

Ferdian, R Bayu, Mohd Din \& M Gaussyah, "Penetapan Kerugian Negara Dalam Perkara Tindak Pidana Korupsi” (2018) 2:3 Syiah Kuala Law J 320-337.

Firmansyah Arifin et all, Lembaga Negara dan Sengketa Kewenangan Antarlembaga Negara (Jakarta: Konsorsium Reformasi Hukum Nasional (KRHN), 2005).

Gusman, Erry, "Kedudukan BPKP dalam Mengaudit Kerugian Keuangan Negara Pasca Putusan Mahkamah Konstitusi Nomor: 31/PUUX/2012” (2019) 1:3 Ensiklopedia Soc Rev 348-357.

Hadi, Syofyan, "Fungsi Legislasi Dalam Sistem Pemerintahan Presidensil (Studi Perbandingan Indonesia dan Amerika Serikat)" (2013) 9:18 DIH J Ilmu Huk 78-84.

—_, "Prinsip Checks And Balances Dalam Struktur Lembaga Perwakilan Rakyat Di Indonesia (Studi Terhadap Usulan Perubahan Kelima UUD NRI Tahun 1945)” (2014) Edisi: Jan Mimb Keadilan 49_ 59.

Hadjon, Philipus M, Pengantar Hukum Administrasi Indonesia (Yogyakarta: Gajah Mada University Press, 2011). 
HR, Ridwan, Hukum Administrasi Negara (Jakarta: PT Raja Grafindo Persada, 2013).

Huda, Ni'matul, "Potensi Sengketa Kewenangan Lembaga Negara dan Penyelesaiannya di Mahkamah Konstitusi" (2017) 24:2 J Huk IUS QUIA IUSTUM 193-212.

Illahi, Beni Kurnia \& Muhammad Ikhsan Alia, "Pertanggungjawaban Pengelolaan Keuangan Negara Melalui Kerja Sama BPK dan KPK" (2017) 3:2 Integritas J Antikorupsi 37-78.

Kelsen, Hans, Hans Kelsen, General Theory of Law and State, translated by Anders Wedberg (New York: Russell \& Russell 1961).

Mashabi, Sania, "ICW: Ada 169 Kasus Korupsi Sepanjang Semester I 2020", (2020), online: <https://nasional.kompas.com/read/2020/09 /29/16112851/icw-ada-169-kasus-korupsi-sepanjang-semester-i$2020>$.

Mulyosudarmo, Suwoto, Peralihan Kekuasaan: Kajian Teoritis dan Yuridis terhadap Pidato Nawaksara (Jakarta: Gramedia Pustaka Utama, 1997).

Paeh, Karel Antonius, "Pengembalian Kerugian Keuangan Negara Berdasarkan Rekomendasi Badan Pemeriksa Keuangan (BPK) Hubungan Dengan Unsur Kerugian Negara dalam Tindak Pidana Korupsi” (2017) 5:2 J Kat 49-56.

Quah, Jon ST, "Combating police corruption in five Asian countries: a comparative analysis" (2019) 9:2 Asian Educ Dev Stud 197-216.

Raba, Mieke Rayu, "Peran Badan Pemeriksa Keuangan (BPK) Dalam Melakukan Pemeriksaan Terhadap Pengelolaan Keuangan Negara Untuk Mewujudkan Pemerintahan yang Baik Menurut UU No. 15 Tahun 2006” (2017) 6:3 Lex Crim 152-160.

Ramadani, Rizki, "Lembaga Negara Independen Di Indonesia Dalam Perspektif Konsep Independent Regulatory Agencies” (2020) 27:1 J Huk Ius Quia Iustum 169-192.

Ramadhan, Ardito, "Catatan ICW, Tren Penindakan Korupsi Turun Jadi 271 Kasus”, (2020), online: <https://nasional.kompas.com/read/2020/ 
02/18/16532131/catatan-icw-tren-penindakan-korupsi-turun-jadi271-kasus>.

Rampengan, Mahdalena Deisi, "Fungsi Badan Pemeriksa Keuangan Dalam Pemberantasan Tindak Pidana Korupsi” (2014) 2:3 Lex Soc 44-51.

Rampengan, Margareth Carla, "Fungsi Laporan Hasil Pemeriksaan (Lhp) Badan Pemeriksa Keuangan Dalam Kasus Tindak Pidana Korupsi” (2013) 2:2 Lex Crim 172-181.

Santoso, M Agus, "Dampak Penjatuhan Pidana Korupsi Bagi Pegawai Negeri Yang Sedang Menjalankan Tugas Administrasi Negara” (1969) 7:2 J Borneo Adm 129-153.

Setiawan, Adam, "Eksistensi Lembaga Pengawasan Pengelolaan Keuangan Negara” (2019) 49:2 J Huk Pembang 265-278.

Siallagan, Haposan, "Problematics on Separation of Powers Theory Implementation" (2015) 15:3 J Din Huk 324-330.

Sunarto, "Prinsip Checks and Balances Dalam Sistem Ketatanegaraan Indonesia" (2016) 45:2 Masal-Masal Huk 157-163Tuanakotta, Theodorus M, Menghitung Kerugian Keuangan Negara dalam Tindak Pidana Korupsi (Jakarta: Salemba Empat, 2009).

Rosyadi, Muhammad Imron, "Wewenang Badan Pemeriksa Keuangan dan Badan Pengawasan Keuangan dan Pembangunan Dalam Menilai Kerugian Keuangan Negara" (2016) Mimb Keadilan 26-53.

Yulistyowati, Efi, Endah Pujiastuti \& Tri Mulyani, "Penerapan Konsep Trias Politica Dalam Sistem Pemerintahan Republik Indonesia: Studi Komparatif Atas Undang-Undang Dasar Tahun 1945 Sebelum Dan Sesudah Amandemen” (2017) 18:2 J Din Sos Budaya 328-338. 